\title{
Fungal and Insect Pests of the Edible Mushroom Pleurotus ostreatus
}

\author{
Gbemisola H. OYEBAMIJI ${ }^{1}$, Gbolagade S. JONATHAN ${ }^{1}$, \\ Damilare Stephen AKINYEMI²* Kehinde K.O. POPOOLA ${ }^{3}$
}

\author{
${ }^{1}$ University of Ibadan, Department of Botany, Ibadan, Nigeria; Gbemisolaoyebamiji@yahoo.com; sg.jonathan@mail.ui.edu.ng \\ 2Obafemi Awolowo University, Department of Botany, Ile-Ife, Nigeria; sakinyemi@oauife.edu.ng ("corresponding author) \\ ${ }^{3}$ University of Ibadan, Department of Zoology, Ibadan, Nigeria; kok.popoola@mail.ui.edu.ng
}

\begin{abstract}
Pleurotus ostreatus is an edible mushroom cultivated worldwide, with economic, nutritional and medicinal values, which requires a shorter growing period compared to other edible mushrooms. Fungal and insect pests of cultivated $P$. ostreatus were examined. Fungi from infected mother spawn of $P$. ostreatus were isolated, characterized and identified, while various insect pests on $P$. ostreatus were also collected and analysed. The plates showing micrographs, morphological and cultural characteristics of fungal isolates obtained were recorded. Fungi species isolated from infected mother spawn of $P$. ostreatus were identified as Aspergillus flavus, A. niger, Cladosporium sp., Penicillium oxalicum, Fusarium oxysporium and F. verticilliodes. The growth of Cladosporium sp. was slow on Potato Dextrose Agar (PDA) plates compared to Aspergillus sp. and Fusarium sp. which was very fast. Insect belonging to the orders Collembola, Diptera and Araneae were encountered on the cultivated P.ostreatus. These groups of insects were found at adult stage of life. Infestation by order Collembola (springtail) on $P$. ostreatus was found to be higher in incidence with percentage composition of $50.0 \%$, followed by order Diptera (fruit flies) and order Araneae (spider) with $33.3 \%$ and $16.67 \%$ composition respectively. Distinguishing features of each pest and the features of damage done on mushroom were also observed and recorded.
\end{abstract}

Keywords: cultural; morphology; mushroom; Pleurotus ostreatus

\section{Introduction}

Mushroom is the fleshy, spore bearing fruiting body of a fungus, typically produced above ground on soil or on its food source (Jonathan and Adeoyo, 2011). Morphologically, mushroom develops from a nodule, a pinhead, less than two millimetres in diameters, called a primordium, which is typically found on or near the surface of the substrate. It is formed within the mycelium, the mass of thread like hyphae that make up the fungus (Metzler and Metzler, 1992). Among the edible mushrooms produced worldwide, Agaricus bisporus is the most cultivated one (38\%), followed by the species of the genus Pleurotus (25\%) and Lentinula edodes (10\%) (Moda, 2008). There are clearly two mushroom markets: one referring to the most commercialized species, Champignon (Agaricus bisporus) and another that gathers exotic mushrooms, including species of L. edodes, Pleurotus sp., Auricularia sp., Flamulina velatipes, Grifola frondosa, Hypsizygus marmoreas, Pholiota nameko, Tremella fuciformis and Volvariella sp. (Furlani et al., 2005). Mushrooms are the richest source of vegetable proteins, containing 31-40\% of protein (Chang and Hayes, 1978). Mushrooms are low-calories food, usually eaten cooked or raw and as garnish to a meal. Dietary mushrooms are good source of B vitamins such as riboflavin, niacin and pantothenic acid and the essential minerals, selenium, copper that help the body to produce red blood cells (Jonathan et al., 2008). Fat, carbohydrate and calories content are low, with absence of vitamin $\mathrm{C}$ and sodium. Mushrooms have low lipid content, being considered healthy foods (Smiderle et al., 2008). However, there are certain abnormalities of several abiotic origins that occur in mushrooms. Such abnormalities include formation of stroma, formation of scales or crocodile skins, changes in colour of fruit bodies, outgrowth on mushroom cap, long stipe, small cap on a normal stipe, rosecomb and scaling (Singh et al., 1991; Gbolagade, 2006).

The various insect pest associated with mushrooms include flies such as cecids, phorids, housefly (Musa domestica), sciarids and stable fly (Stomoxys calcitrans) (Ajayi and Jonathan, 2004). The flies belong to the order Diptera. 
380

sciarid flies also known as fungus gnats belong to the family Sciaridae, while species include: Sciara multiselta, Sciara agaris, Lyeoriella mali. Cecid flies also known as gall midges belong to the family Cecidomydae and species include: Mycophila spayeri, Mycophila borresi, Heteropeza pygmaea. Phorid flies belong to the family Phoridae and species include: Megaselia nigra, Megaselia halterata. Mites which are found in straw and manure, include small mushroom mites (Tarsonemas sp.), straw or hay mites (Tyrophagus sp.). The springtails which are tiny insects include species such as Isotoma simplex, Lepidocrytus sp., Cynaneus sp. (Keil, 1996).

Fungal disease of cultivated mushroom include dry bubble disease caused by Verticillium fungicola, wet bubble disease caused by Mycogone perniciosa, cobweb or dectylim mildew caused by Cladobotryum dendroides (Hypomyces rosellus), green mould caused by Trichoderma (Gbolagade, 2005; Fasidi et al., 2008).

Pleurotus ostreatus is an edible white rot fungus commonly known as oyster mushroom, which can be cultivated on a variety of organic substrates. It belongs to the kingdom Fungi, Division Basidiomycota, class Agaricomycetes, Order Agaricales, family Pleurotaceae, Genus Pleurotus, which include many other species such as P. flobellotus, P. sojar-caju, P. eryngii, P. osfreafies, $P$. floride and P. sapidus. (Amuneke et al., 2011; Jonathan et al., 2012).

The main goal of the present research was to investigate the fungal and insect pest associated with Pleurotus ostreatus. The specific aims were (1) to isolate and characterize various fungi associated with the cultivated $P$. ostreatus and (2) to investigate and identify the occurrence of insect pest in cultivated $P$. ostreatus.

\section{Materials and Methods}

\section{Study area}

The study was conducted in the Mycology laboratory, Department of Botany, University of Ibadan, Oyo State. Ibadan is located in Southwestern Nigeria between latitude $7^{\circ} \mathrm{N} 26^{\prime}$ Longitude $3^{\circ} \mathrm{E} 53^{\prime}$ at an altitude of $190 \mathrm{~m}$. The city ranges in elevation from $150 \mathrm{~m}$ in the valley area to $275 \mathrm{~m}$ about sea level (Lyold, 1967). Ibadan has a tropical wet and dry climate with mean monthly temperature and humidity ranging from $23{ }^{\circ} \mathrm{C}$ to $30{ }^{\circ} \mathrm{C}$ and $55 \%$ to $75 \%$ respectively (Onibokun and Faniran, 1995).

\section{Sterilization of media and glassware}

All glassware used were thoroughly washed with detergent, rinsed with water and air-dried before sterilization in a hot air oven at $180{ }^{\circ} \mathrm{C}$ for 3 hours. All media employed were prepared according to the manufacturers' specification and then sterilized by autoclaving at $121{ }^{\circ} \mathrm{C}$ for $15 \mathrm{~min}$. Aseptic condition was maintained by swabbing the bench surface with $70 \%$ ethanol and flaming of inoculating needles over a spirit lamp before and after inoculation.

\section{Preparation of media}

Potato Dextrose Agar (PDA) was used for the isolation of the organisms; it was prepared following the manufacturer's guide $(39 \mathrm{~g}-1,000 \mathrm{ml})$. Also sterilization at
$121{ }^{\circ} \mathrm{C}$ for $15 \mathrm{~min}$ was done before it was poured in sterile Petri dishes.

\section{Collection of mushroom and insects samples}

Mother spawn of Pleurotus ostreatus was collected from the mushroom unit of pathology section of Forest Research Institute of Nigeria, Jericho, Ibadan (FRIN).

\section{Isolation of fungi from mushroom samples}

The mushrooms (Pleurotus ostreatus) were brought to the laboratory for isolation. For the experiment, $2 \mathrm{~g}$ of infected region of $P$. ostreatus were plated on Potato Dextrose Agar (PDA). Thereafter, $0.5 \mathrm{mg}$ of Streptomycin was added to the PDA to prevent bacterial contamination. The isolates were plated in triplicates and the plates were incubated at room temperature $\left(25 \pm 2{ }^{\circ} \mathrm{C}\right)$ for 7 days according to the procedure described by Gbolagade (2006).

\section{Selection of pure culture}

After incubation, the plates observed for fungal growth and colonies were randomly selected. The isolates were subcultured 5-6 times on PDA. Pure cultures were prepared on slants and then stored in the refrigerator (Alexopolous et al., 1996).

\section{Identification offungi}

Identification of fungi was carried out with the aid of slide cultures, temporary mounts with cover slips before observation under the microscope using $\times 40$ objective lens. The slides were labelled and photographed, and final identification was done using published keys and compendium of soil fungi (Domsh et al., 1980).

\section{Morphological and cultural characterization of isolates}

Pure cultures of the fungal strains were prepared by subculturing them separately on fresh plates containing PDA before incubation for 3-7 days. These organisms were thereafter characterized morphologically using cultural features which include surface (front), reverse (back) colour (Banrnetand Hunter, 1972).

\section{Collection and identification of insects}

Insect pests were collected from mushroom by hand picking method. During collection of springtails, the selected mushrooms were covered with polythene bag with dimension $(5 \times 7 \mathrm{~cm})$ to allow the insects to hop in. Subsequently, the collected springtails were taken to the laboratory for identification. On the other hand, the fruit flies and the spider were collected using bare hand from the mushroom into collecting bottle and taken to the laboratory. The collection was done at Beejay Ventures Odo-ona Kekere. The area coordinate reading was latitude $07 \mathrm{~N}^{\circ} 17^{\prime}$ and longitude $03^{\circ} \mathrm{E} 51^{\prime}$. The insects were picked from species of $P$. ostreatus and preserved in specimen bottle $(50 \mathrm{ml})$ containing $4 \%$ formalin solution (Kim and Hwang, 1996). Insects collected were identified in the Entomology Unit Department of Zoology, University of Ibadan, using basic insect identification key after viewing under an Olympus dissecting microscope $(\times 32)$. Subsequently, they were recorded photographically using Sams ung 10.2 mega pixel. The collected species were stored in the laboratory for reference purpose. 


\section{Results}

Morphology, cultural characteristics and microscopic examination of fungal isolates from infected Pleurotus ostreatus

Fungal isolates belonging to the genera Aspergillus, Cladosporium, Penicillium and Fusarium were isolated from infected $P$. ostreatus (Table 1). The figures showing the micrographs, morphological and cultural characteristics of the fungal isolates obtained are shown below. The isolates were Aspergillus flavus, Aspergillus niger, Cladosporium sp., Penicillium oxalicum, Fusarium oxysporium and $F$. verticillioides.

\section{Aspergillus flavus}

The colonies on PDA at $27^{\circ} \mathrm{C}$ attained a diameter of 3$5 \mathrm{~cm}$ within 7 days and consisted of a dense felt yellowishgreen conidiosphores or mature vesicles bearing phalides over their entire surface with a cream reverse. Rapid growth with usually two sets of sterigmata and with spiny stalks were observed. Some colonies appeared colourless (hyaline) or brightly coloured also termed moniliaceous. Conidiosphores terminated in a vesicle covered with either a single phalides (uniseriate) or a layer of subtending cells (metulae) which bears whorls of phialides known as biseriate structure. Conidia were one celled, smooth-orrough-walled, hyaline or pigmented and basocatenate, forming long dry chains which maybe divergent (radiate or aggregated in compact columns) up to $1.0 \mathrm{~mm}$, while some isolates were up to $2.5 \mathrm{~mm}$ in length. Texture was woolly to cotton or granular. Some species may produce Hulle cells or sclerotia. Sclerotia when present were dark brown. A clear to pale brown exudates may be present in some isolates.
Phalides borne directly on the vesicle or metulae, $6 \times 10 \times 4.0$ -

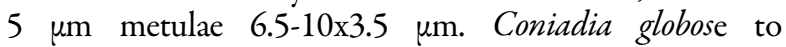
subglobose and spiny (Fig. 1).

\section{Aspergillus niger}

Colonies on PDA at $27^{\circ} \mathrm{C}$ attained a diameter of 4-5 $\mathrm{cm}$ within 7days, consisting of a compact white or yellow felt with a dense layer of dark brown to black conidiospores. Mycelial or threadlike hyphae were divided by a septum and transparent conidiosphores (asexually produce fungal spores). A. niger usually range from 900-1,600 um in length and contain globose to subglobose, round, radiate head vesicles ranging from 40-60 um in diameter. Each globose vesicle was covered with biseriate phialides which are projections from the conidiosphore of $A$. niger. Conidiospores stipes, long, smooth walled hyaline, but also brown colour phaliades borne on metulae which was the site where conidiogenous cell was created; phialides borne on metulae,7.0-9.5x3.5 um, metulae hyaline, brown often septate,15-25 x 4.5-6.0 um. The phialides go through a process of blastic basipetal conidiogenous to create globose mitospores which have a diameter that ranges from 3 to 5 um. A. niger is differenciated from other Aspergillus due to the production of carbon black or very dark black spores from biseriate phialides. Conidiospores and spores have conspicuous ridges or spines not arranged in rows (Fig. 2).

\section{Cladosporium sp.}

Growth of Cladosporium colonies was moderate on PDA at $25^{\circ} \mathrm{C}$ and the texture was velvety to powdery. Colonies were rather slow growing species, produced olivegreen to brown or blackish brown, but also sometimes grey, buff or brown, suede-like to floccose, often becoming powdery due to the production of abundant conidia.

Table 1. Morphology, cultural characteristics and microscopic examination of fungal isolates from infected Pleurotus ostreatus

\begin{tabular}{|c|c|c|c|c|c|}
\hline $\begin{array}{c}\text { Isolate } \\
\text { code }\end{array}$ & Isolates & Growth pattern & Surface colour & Reverse colour & Microscopic examination \\
\hline A & Aspergillus flavus & Rapid & Yellowish green & Cream & $\begin{array}{l}\text { Phialides borne directly on the vesicle with } \\
\text { coniadia head typically radiate and } \\
\text { conidiospores coarsely roughened. }\end{array}$ \\
\hline B & Aspergillus niger & Rapid & Blackish brown & Creamish yellow & $\begin{array}{c}\text { Conidia head with metulae and phialides, } \\
\text { conidiospores stipes long, smooth walled and } \\
\text { hyaline. }\end{array}$ \\
\hline $\mathrm{C}$ & Cladosporium sp. & Slow & Olive green & Blackish brown & $\begin{array}{l}\text { Conidiospores tall, dark, upright, branched } \\
\text { variously near the apex, conidia ovoid to } \\
\text { cylindrical and irregular in shape. }\end{array}$ \\
\hline $\mathrm{D}$ & Penicillium oxalicum & Rapid & Dark green & Yellowish green & $\begin{array}{l}\text { Conidiospores branched near the apex, } \\
\text { conidia hyaline, one celled, ovoid in dry } \\
\text { basipetal chains ending in phialides. }\end{array}$ \\
\hline E & Fusarium oxysporium & Rapid & Creamy & Yellowish milk & $\begin{array}{l}\text { Macroconidia with 3-septate, short to medium } \\
\text { length, straight to slightly curved, relatively } \\
\text { slender and thin walled. Microconidia oval in } \\
\text { shape with } 0 \text {-septate. }\end{array}$ \\
\hline $\mathrm{F}$ & Fusarium verticillioides & Rapid & Greyish orange & Orange & $\begin{array}{l}\text { Macroconidia abundant, single celled, oval to } \\
\text { club shape, } 3-5 \text { septate and are relatively long, } \\
\text { slender and thin walled. }\end{array}$ \\
\hline
\end{tabular}


382

Vegetative hyphae, conidiospheres and conidia were equally pigmented, formed in simple or branching chains. Conidiophores were more or less distinct from vegetable hyphae, erect, tall, straight or flexuous, dark, upright, unbranched or branched only in the apical region, clustered or single, with geniculate sympodial and elongate in some species; conidia (blastospores) smooth, 1-to-4-celled, verrucose or echinulate, with distinct dark hilum were produced in branched acropetal chains, variable in shape and size, ovoid to cylindrical and irregular, some typically lemon-shaped. The term blastocanate is often used to describe chains of conidia where the youngest conidium is at the apical or distal end of the chain. The conidia closest to the conidiophores and where the chains are branch are usually 'shield shape'. The presence of shield shape conidia, distinct helium and chains of conidia that readily disarticulate, are diagnostic for the genius Cladosporium (Fig. 3).

\section{Penicillium oxalicum}

Colonies were dark green on PDA with a yellow reverse, powdery and compact with rapid growth. Conidiospores arising from a single or less often synemata branched near the apex, penicillate, ending in phalides. The conidiophore was asymmetrical. Conidial were formed in long thin chains which shine like threads of silk under illumination. When an agar plate containing penicillium is tapped, the conidia fall away in crust or sclumps. The conidia were relatively large, relatively elliptical and smooth, round and unicellular; conidial hyaline, 1 celled, mostly globose or ovoid, in dry basipetal chains. Penicillium oxalicum is recognised by their dense brush like spore bearing structures. Penicillium species tend to have small hyphae, this makes protoplasmic movement difficult to detect. The small hyphae also tend to smaller peripheral growth (Fig. 4).

\section{Fusarium oxysporium}

Colony morphology on PDA varied widely. Mycelia may be floccose, sparse or abundant and range in colour from white to pale violet. Abundant pale orange or pale violet macroconidia were produced in a central spore mass in some isolates. Small pale brown, blue to blue-black or violet sclerotia may be produced abundantly by some isolates. F. oxysporum usually produces a pale to dark violet or dark magenta pigment in the agar, but some isolates produce no pigment at all. Some isolates of $F$. oxysporum mutate readily to the pionnotal form or to a flat "wet" mycelial colony with a yellow to orange appearance when cultured on PDA. Macroconidia have 3-septate, short to medium length, straight to slightly curved, relatively slender and thin walled. Its apical cell morphology is tapered and curved, while the basal cell morphology is foot shaped to pointed. It is abundant in sporodochia and occasionally from hyphae growing on the agar surface. The microconidia are oval, elliptical or kidney shaped and usually 0 -septate. It is abundant in the aerial mycelium and appears as false heads. The conidiogenous cells have short monophialides (Fig. 5).

\section{Fusarium verticillioides}

Initially cultures have white mycelia, but may develop violet pigments with age. Pigmentation in the agar varies, ranging from no pigmentation or grayish orange to violet grey, dark violet or dark magenta (almost black) in others.
Blue-black sclerotia may develop in some isolates, but are not diagnostic although they may be indicative of a high level of female fertility.

Sporodochia in the macroconidia may be tan or orange in colour and present as discrete entities or as a pseudopionnotal mass. The macroconida which has 3- to 5 -septate are relatively long and slender, slightly falcate or straight, and thin walled. The microconidia abundant in the aerial mycelia is oval to club shaped, with a flattened base and usually 0 -septate. Long chains are common, aerial mycelium but small aggregates of a few spores occur occasionally. The conidiogenous cells consists monophialides, which are occasionally produced in pairs to give a "rabbit ear" appearance (Fig. 6).

\section{Springtails}

Springtails are minute, to medium wingless entognaths insect less than $0.5 \mathrm{~cm}$ in length. The springtails fed on mycelium in compost, resulting in disappearance of mycelium from spawn compost. They also affected fruiting bodies of some mushrooms and caused slight pitting or browning at feeding sites. They congregated at base of stipe and ate out mycelia strands (Fig. 7).

\section{Fruit flies}

Drosophila melanogaster is a species of Diptera, in the family Drosophilidae. They are about $0.2-0.5 \mathrm{~cm}$ in length. They also fed on mushrooms by sucking sap fluxes hence causing damage (Fig. 8).

\section{Spider}

Spiders (Arachnida) are air breathing arthropods that have eight legs and chelicerae with fangs that inject venom. They visited the mushroom to sap nutrient, bore hole into the stipe of mushroom and caused mycelium damage (Fig. 9).

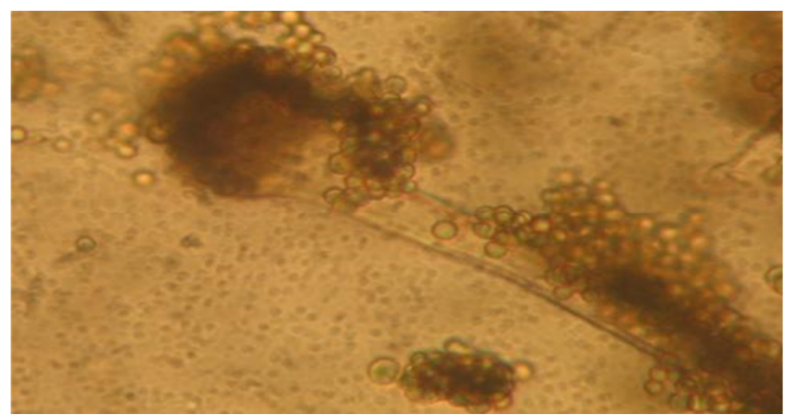

Fig. 1. Micrograph of Aspergillus flavus

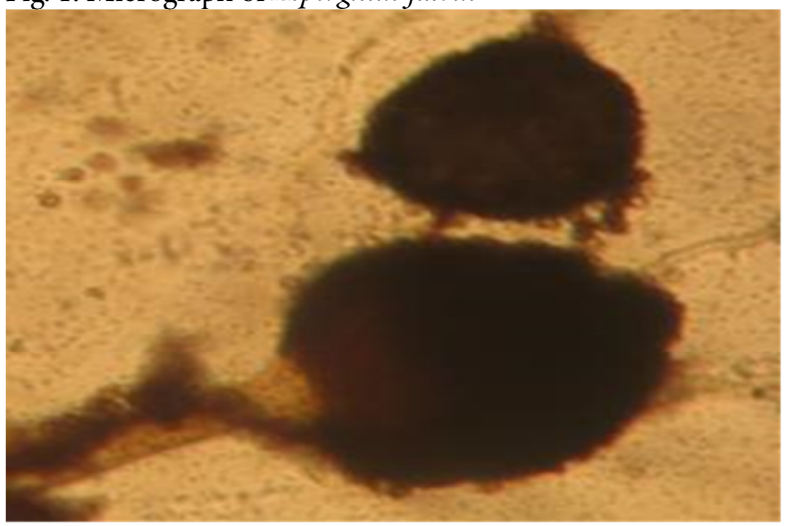

Fig. 2. Micrograph of Aspergillus niger 


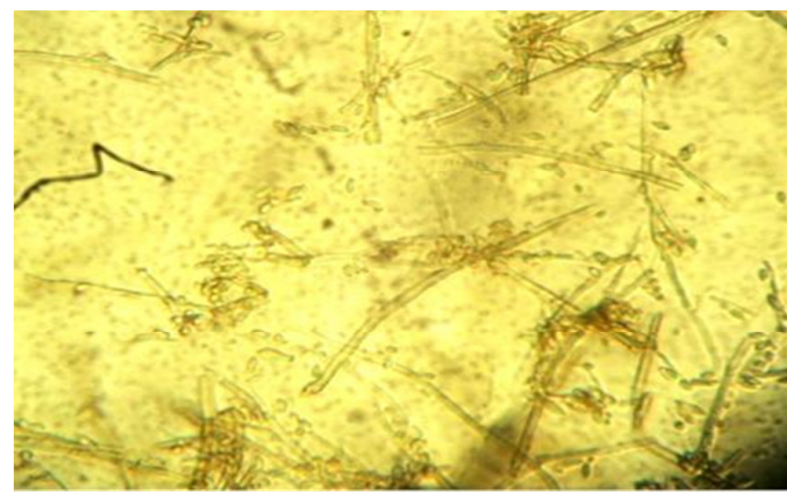

Fig. 3. Micrograph of Cladosporium sp.

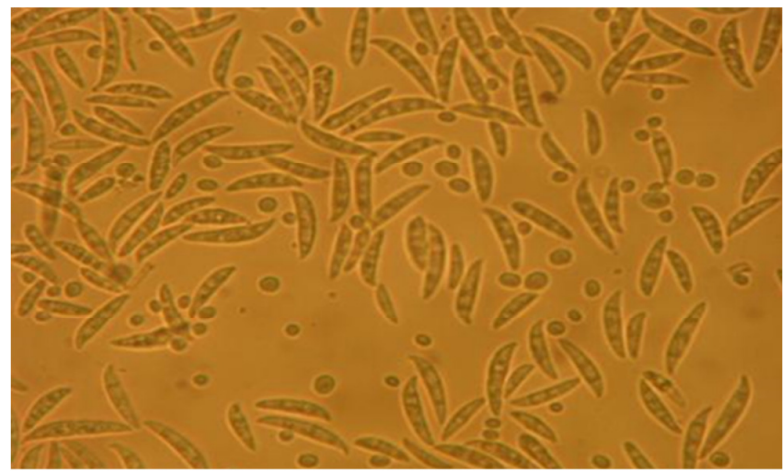

Fig. 5. Micrograph of Fusarium oxysporium

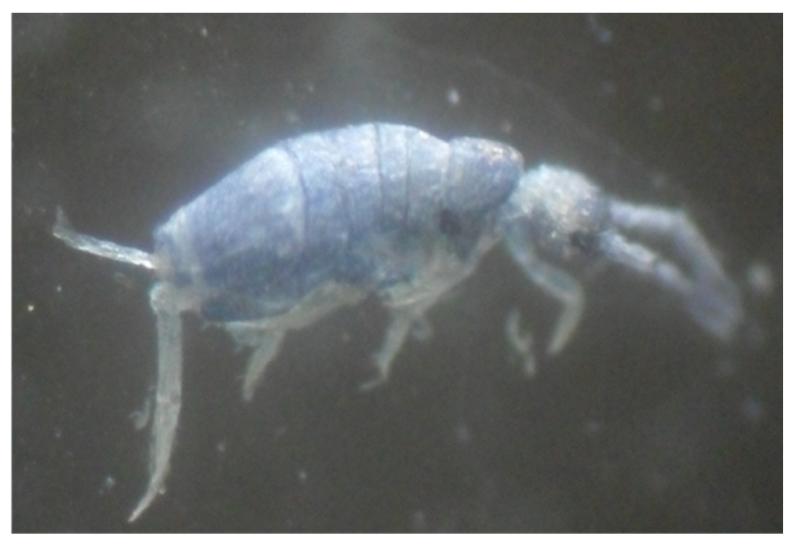

Fig. 7. Lepidocyrtus cyaneus (Silver springtail), with visible furcular

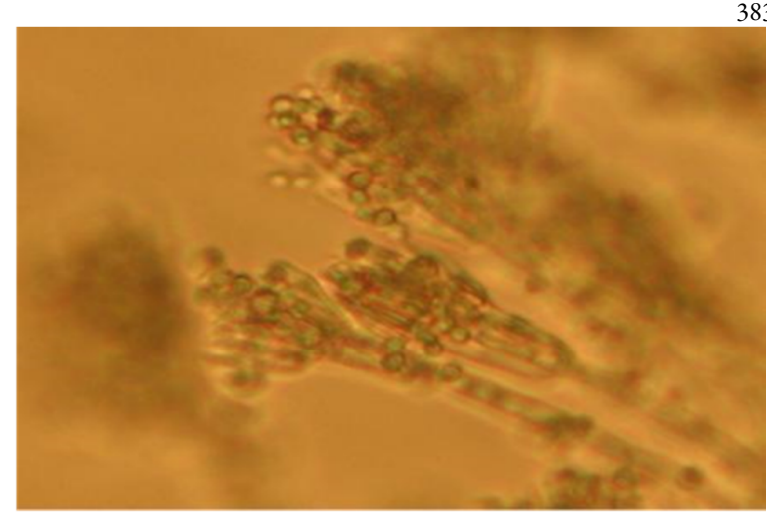

Fig. 4. Micrograph of Penicillium oxalicum

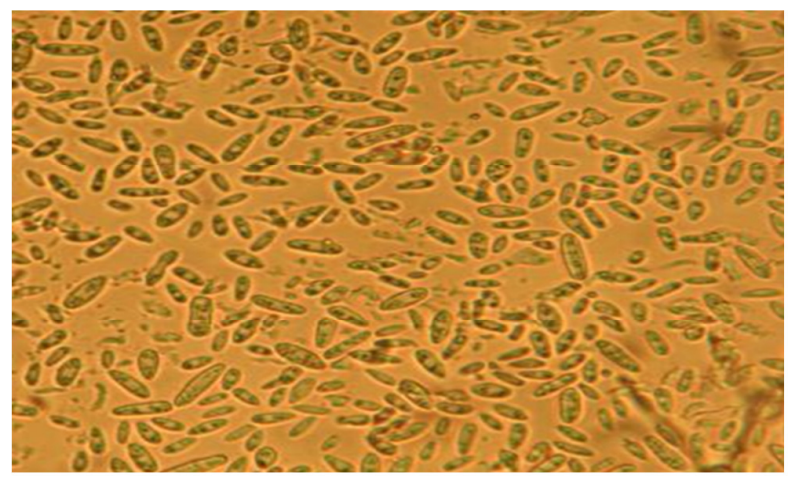

Fig. 6. Micrograph of Fusarium verticillioides

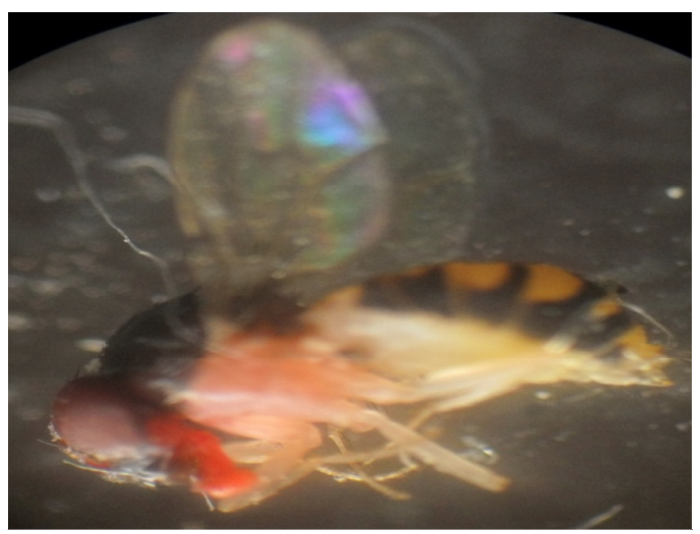

Fig. 8. Drosophila melanogaster (fruit fly)

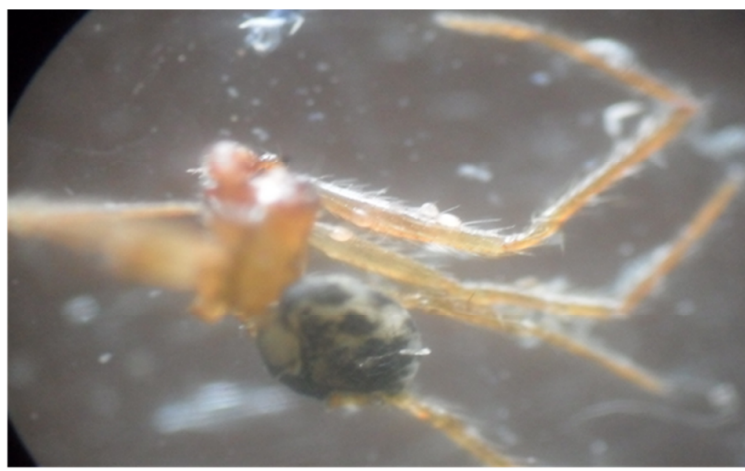

Fig. 9. Arachnida (spider) 
384

Table 2. Number of insect orders encountered on cultured mushroom (Pleurotus ostreatus)

\begin{tabular}{|c|c|c|c|c|c|c|c|}
\hline \multicolumn{8}{|c|}{ Encountered } \\
\hline Collection site & $\begin{array}{c}\text { Date of } \\
\text { collections }\end{array}$ & $\begin{array}{c}\text { Mushroom } \\
\text { species studied }\end{array}$ & $\begin{array}{l}\text { No of } \\
\text { insects }\end{array}$ & Insect order & Common name & Scientific name & Life stage \\
\hline \multirow{6}{*}{$\begin{array}{c}\text { Beejay } \\
\text { ventures, } \\
\text { Odo ona }\end{array}$} & $20 / 03 / 2013$ & P. ostreatus & 3 & Collembola & Springtail & $\begin{array}{l}\text { Lepidocyrtus } \\
\text { cyaneus }\end{array}$ & Adult \\
\hline & & & & Diptera & Fruittly & $\begin{array}{c}\text { Drosophila } \\
\text { melanogaster }\end{array}$ & Adult \\
\hline & $10 / 04 / 2013$ & & & Araneae & Spider & Arachnida & Adult \\
\hline & $10 / 04 / 2013$ & P. ostreatus & 1 & Collembola & Springtail & $\begin{array}{l}\text { Lepidocyrtus } \\
\text { cyanus }\end{array}$ & Adult \\
\hline & $30 / 04 / 2013$ & P. ostreatus & 2 & Collembola & Springtail & $\begin{array}{l}\text { Lepidocyrtus } \\
\text { cyanus }\end{array}$ & Adult \\
\hline & & & & Diptera & Fruitfly & $\begin{array}{c}\text { Drosophila } \\
\text { melanogaster }\end{array}$ & Adult \\
\hline
\end{tabular}

\section{Discussion}

Fungal pathogens isolated from infected mother spawn of Pleurotus ostreatus were identified as Aspergillus niger, Aspergillus flavus, Cladosporium sp., Fusarium oxysporium, Fusarium verticilliodes and Penicillium oxalicum. Similar observations were also reported in accordance with the findings of Jonathan et al. (2012). The morphology and cultural characteristics of fungal isolates observed from infected mother spawn of $P$. ostreatus also agrees with the observation made by Sigler et al. (2003) and Jonathan $e$ t al. (2012). Many of these fungi are parasite on cultivated plants and on other fungi (mushroom) causing extensive damage to agriculture and pose risk to indoor production during the fruiting stage (Lillian, 2007). Fungal spores can also cause allergies and fungi from different taxonomic groups can evoke allergic reactions (Gryzenhout et al., 2006).

The use of sterilized casing soil, proper disposed of spent compost, proper hygiene and sanitation are essential to avoid primary infection (Sharma, 1994). Wuest and Bengtson (1982) suggested that physical treatment for thirty-minute treatment with aerated steam at $60^{\circ} \mathrm{C}$ and 82 ${ }^{\circ} \mathrm{C}$ hinder spore germination. Tregoff and Ricard (1976) suggested that trichoderma propagles/litre $/ \mathrm{m}^{2}$ can be sprayed biologically on casing soil to control fungal diseases on naturally infected mushrooms. Geijn (1977) recommended that fungal disease of oyster mushroom $(P$. ostreatus) can be controlled chemically by spraying with carbendazin benomyl or thiophenate methyl at 100, 150 and $200 \mathrm{~g} / 100 \mathrm{~m}^{2}$ respectively in 100-150 litres of water immediately after casing.

Generally, proper pasteurization and conditioning of compost, sterilizing the supplement before use and using correct concentration of formalin (maximum 2\%) was advised to prevent fungi diseases. In order to decide the most effective measures for controlling fungal diseases in mushroom, it is necessary to understand the size of the initial innoculum, density, the rate at which the diseases develop and spreads and the time when the infection takes place (Zhang, 1990). Fungal disease could be best controlled by a complete careful farm management and hygiene and also with the application of the recommended fungicides such as benomyl and chlorothanil (Fasidi et al., 2008).
The infestation of $P$. ostreatus with several arthropod pests such as springtails and fruit flies which were found on the mushrooms also conforms to the observations made by Jonathan et al. (2012) who encountered Collembola and Diptra orders of insects. On the other hand, spider which belongs to the order Araneae was encountered on $P$. ostreatus during the harvesting period. This could be attributed to high nutritional content of the staple diet of spider which was rotten mushrooms and other microscopic insects.

The increase in number of insects found and the damage done on the mycelia is related to their feeding habit, which could be associated with the high level of sugar alcohol in $P$. ostreatus. Springtails enter into mushroom house along with organic matter, feed on gills resulting in the destruction of gill lining, eat up edges of the pileus and lamella. Also, ingest the mycelium. Furthermore, from this work springtails may be implicated in the damage of mycelium by feeding on their hyphae, also transmitting fungal infection. The observed damages done by the insects and transmission of fungal infection in this study supported the findings of Lillian (2007) and Jonathan et al. (2012). Springtails congregate at the base of stipe and cut out mycelia strands due to the cool nature of the environment (Imms, 1965). The Dipterans encountered were moderately sized, with low level of infestation compared to the Collembola. The ability of fruit flies to appear from "nowhere" and the facts that they seem to be everywhere when foods are exposed are source of amazement to most home owners and individuals in food industry. For instance, the predominance of insects in $P$. sajor caju could be attributed to open gilled sporocarps of this mushroom which provided ample hiding space for grubs, larvae and adults of springtail Spiders also visited the mushroom to sap nutrient, bore hole into the stipe of mushroom and cause mycelium damage (Kumar et al., 2012).

The present study provides useful information on how the various arthropod pests have caused damage to these mushrooms having the potential to cause economic loss, reduce mushroom yield and quantity. Also, insect have been found to inhabitate mushroom in order to complete their life cycle. In this process, they reduce the growth rate of mushroom, bore holes on different parts of mushroom and thereby reducing the market value of the mushroom. 
Measures to minimize insects' infestation can be achieved through maintenance of good hygienic environment for the mushroom, pasteurization of compost and casing material. Others are proper disposal of spent compost, disinfecting the composting yard, empty growing room with $0.05 \%$ malathion and mixing diazinon $30 \mathrm{ppm}$ $(15 \mathrm{ml}$ diazinon after diluting with water) in $100 \mathrm{~kg}$ of compost at the time filling. For controlling infestation during spawn run and cropping periods, malathion or dichlourvos at $0.025-0.05 \%$ should be sprayed and observed for a period of 2 to 5 days (Sandhu and Batthall, 1987). According to Cantelo (1980), reducing fly numbers without using insecticides requires a good understanding of fly biology and behaviour. Thereafter, nontoxic chemicals such as Diflubenzuron may be applied in order to arrest the development of insect larvae (Fasidi et al., 2008).

Mushroom house vents must have air filters such as screen net. However, to minimize disease problems and favour the growth of mushrooms, it is important to provide optimum growing condition and carry out practices based on the full understanding of biology of mushroom and the pests. This knowledge involves biology and ecology of mushroom, plant pathology, entomology and zoology.

\section{Conclusions}

Certain associations were observed between the mushroom $P$. ostreatus, fungi and insect pests. Four different fungi genera and three arthropods orders were encountered in association with the studied mushroom. These fungi and insects exhibited parasitic associations with the mushroom which resulted in the use of the mushroom as food among other uses. Their presence resulted in damages recorded on mushroom due to feeding activities, thus in turn reduce their market values and resulting in financial loss to the growers. Measures to minimize insects' infestation can be achieved through maintenance of good hygienic environment for the mushroom, pasteurization of compost and casing material. Others are proper disposal of spent compost, disinfecting the composting yard. However, to minimize disease problems and favour the growth of mushrooms, it is important to provide optimum growing condition and carry out practises based in combination with knowledge in mushroom pathology and entomology.

\section{References}

Ajayi EJ, Jonathan SG (2004). Plant pest disease: An approach to control methods. JacobOjo and Sons.

Alexopolous CJ, Mims CW, Blackwell M (1996). Introductory mycology. $4^{\text {th }}$ Edition.John Wiley \& Sons, New York.

Amuneke EH, Dik KSK, Ogbulie JN (2011). Cultivation of Pleurotus ostreatus: An edible mushroom from agro base waste products. Journal of Microbiology and Biotechnology Research 1(3):1-14.

Banrnet HL, Hunter BB (1972). Illustrated genera of imperfect fungi. Minneapolis Burgress Publishing Company. Minneapolis, $\mathrm{MN}$.

Cantelo WW (1980). Control of mushroom flies without chemicals. Mushroomnews 28(4):9-17.

Chang ST, Hayes WA (1978). The biology and cultivation of edible mushroom. Academic Press Inc, New Yorkand London.
Domsh, KH, Gam W, Anderson TH (1980). Compendium of soil fungi. Volume 1. Academic Press (London) Ltd.

Fasidi IO, Kadiri M, Jonathan SG, Adenipekun CO, Kutororiji CO (2008). Cultivation of tropical mushroom. Ibadan, Ibadan University Press pp 81.

Furlani RPZ, Godoy HT (2005). Nutritional value of edible mushrooms: a revision. Revista do Instituto Adolfo Lutz 64(2):149-154

Gbolagade JS (2005). Bacteria associated with cutures of Psathyrella altrombonata (pegler), and Schizophyllum commune, Nigerian edible mushroom. Acta Phytopathologica et Entomological Hungarica 40:(23):333-340.

Gbolagade JS, Ajayi A, Oku I, Wankas D (2006). Nutritive value of common wild edible mushroom from southern Nigeria. Global Journal of Biotechnology and Biochemistry $1(1): 16-21$.

Gbolagade SJ (2006). Bacteria associated with compost used for cultivation of Nigeria edible mushrooms Pleurotus tuber-regium (Fr.) Singer and Lentinus squarrosulus Berk. African Journal of Biotechnology 5:338342.

Geijn JV (1977). The control of bubble Verticillium fungicola and Mycogone pemiciosa. Champignoncultuur 2:197-201.

Gryzenhout M, Wingfield BD, Wingfield MJ (2006). New taxonomic concept for the important forest pathogen Cryphonectria parasitica and related fungi. Fems Microbiology Letters 258(2):161-172.

Imms AD (1965). Collembola Spring-tails. A general textbook of Entomology. $9^{\text {th }}$ ed. R75-283. The English language book society London.

Jonathan SG, Ajayi IO, Adegaye A (2008). Biodegradation of Nigeria wood waste by Pleurotus tuber-regium (fries) singer. Bioresource Technology 99:807-11.

Jonathan SG, Bawo DDS, Adejoye DO, Bariyai OF (2012). Studies on biomass production in Auricularia polytrica collected from Wilberforce island, Bayelsa State Nigeria. American Journal of Applied Sciences 6(1):182-186.

Jonathan SG, Adeoyo OR (2011a). Collection, morphological, characterization and nutrient profile of some wild mushroom from Akoko, Ondo state, Nigeria. Natural Products 7(3):123-136

Keil CBO, Bartlett GR (1996). Permethrin resistance in Lycoriella mali (Fiten) (Diptera: Sciaridae) on commercial mushroom farms. MushroomNews 44:8-13.

Kim KC, Hwang CY (1996). An investigation of insect pest on the mushroom (Lentinus edodes, Pleurotus ostreatus) in south region of Korea. Korean Journal of AppliedEntomology35(1):45-51.

Kumar S, Khanna AS, Rana VK (2012). Insect fauna associated with edible mushrooms in Himachal Pradesh. Journal of Insect Science 25(1):2938.

Lillian B, Ricardo CC, Josiana AV, Isabel CFR, Paula B, Letcia ME (2007). Antimicrobial activity and bioactive compounds of Portuguese wild edible mushrooms methanolic extracts. European Food Research Technology 225:151-156.

Moda EM (2008). Increased shelf life of mushrooms Pleurotus soja-cashew in natura with gamma radiation application. Unplubilshed thesis.

Onibokun P, Faniran A (1995). Urban research in Nigeria. IFRA and CASSAD, Ibadan pp 355-357. 
386

Sandhu GS, Batthal DS (1987). Biology of phorid fly, Megaselia sandhui Disney (Diptera: Phoridae) on temperate mushroom. In: Wuest PJ, Royse DJ, Beelman RB (Eds). Cultivating Edible Fungi. Elsevier. Amsterdam pp 395-404.

Sigler L, Verveij PE (2003). Aspergillus, fusarium, and other opportunistic moniliaceous fungi. In: Murray PR, et al., (Eds). Manual of clinical microbiology. Ch. $1168^{\text {th }}$ ed. ASM press. Washington, DC.

Singh K, FrisvadJC, Thraneus U,MathewSB (1991). An illustrated manual on the identification of some seed borne aspergilla, fusania, penicilla and their mycotoxin. Danish government institute of seed pathology for developing countries, Helleruppp 31-69.
Smiderle FR, Carbonero ER, Sassaki GL, Gorin PAJ, Iacomini M (2008) Characterization of a heterogalactan: Some nutritional values of the edible mushroom Flammulina velutipes. Food Chemistry 108:329-333.

Wuest P, Bengtson GD (1982). Penn State Handbook for commercial mushroom growers. The Pennsylvania State University, University Park.

Zhang DH (1990). Study on the prevention of wet bubble in Agaricus bisporus. Zhonguo Shiyongiun 9(5):22-23. 